\title{
MOLECULAR-GENETIC AND PHENOTYPIC CHARACTERISTICS OF DESMOID-TYPE FIBROMATOSIS
}

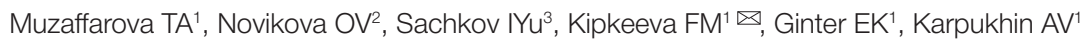

${ }^{1}$ Bochkov Research Center for Medical Genetics, Moscow, Russia

${ }^{2}$ Hertsen Moscow Oncology Research Center, Moscow, Russia

${ }^{3}$ Ryzhikh State Research Center for Coloproctology, Moscow, Russia

Desmoid-type fibromatosis (DF) is a rare mesenchymal tumor occurring in only 2 to 4 people per 1,000,000 population a year. Desmoid tumors are either seen sporadically or in individuals with familial adenomatous polyposis (FAP). The etiology of sporadic DF is uncertain. The aim of this study was to estimate the potential significance of germline mutations in the APC gene in patients with sporadic DF. APC exons were amplified, studied using conformation sensitive gel electrophoresis and then Sanger-sequenced. The obtained data were processed in Statistica 10. Mutations were detected in 6 (12\%) of 51 participants with sporadic DF. Those 6 patients shared a typical DF phenotype characterized by early age of onset ( 5.8 years on average, in contrast to the patients without $A P C$ mutations, who developed DF at 19 years of age; $p=0.02$ ), severe clinical course, multifocal localization on the trunk, and poor prognosis. All of the detected $A P C$ mutations were localized to the $3^{\prime}$-end of the gene. For the purpose of comparison, we analyzed a sample of 12 patients with FAP-associated DF. Of those patients, 6 carried mutations in the APC gene. In the analyzed sample, the patients with FAP and the mutant APC gene developed DF at older age (35 years) than the patients with sporadic DF $(p=0.004)$ and their tumors were not multifocal. This means that sporadic and FAP-associated desmoids have different phenotypes in patients with APC mutations. Patients with sporadic tumors have mutations at the 3 '-end of the APC gene more often than individuals with FAP-associated DF. To our knowledge, this is the first study to characterize the subtype of sporadic desmoid fibromatosis phenotypically determined by germline mutations in the APC gene.

Keywords: sporadic desmoid-type fibromatosis, APC gene, multifocal desmoid tumors, familial adenomatous polyposis

Author contribution: Muzaffarova TA conducted the study, analyzed the literature and wrote the manuscript; Novikova OV, Sachkov IYu provided patients' samples and medical histories; Kipkeeva FM, Ginter EK analyzed the literature and wrote the manuscript; Karpukhin AV organized the study and revised the manuscript.

Compliance with ethical standards: the study was approved by the Ethics committee of Bochkov Research Center for Medical Genetics (Protocol № 3 dated February 09, 2012).

$\square$ Correspondence should be addressed: Fatima M. Kipkeeva Moskvorechie 1, Moscow, 115522; BRCA1@mail.ru

Received: 25.06.2019 Accepted: 13.07.2019 Published online: 18.07.2019

DOI: $10.24075 /$ brsmu.2019.045

\section{МОЛЕКУЛЯРНО-ГЕНЕТИЧЕСКИЕ И ФЕНОТИПИЧЕСКИЕ ОСОБЕННОСТИ СЛУЧАЕВ ВОЗНИКНОВЕНИЯ ДЕСМОИДНОГО ФИБРОМАТОЗА}

Т. А. Музаффарова', О. В. Новикова², И. Ю. Сачков ${ }^{3}$ Ф. М. Кипкеева ${ }^{\circledR}$, Е. К. Гинтер${ }^{1}$, А. В. Карпухин ${ }^{1}$

${ }^{1}$ Медико-генетический научный центр имени Н. П. Бочкова, Москва, Россия

2 Московский научно-исследовательский онкологический институт имени П. А. Герцена, Москва, Россия

${ }^{3}$ Государственный научный центр колопроктологии имени А. Н. Рыжих, Москва, Россия

\begin{abstract}
Десмоидные фибромы (ДФ) - редкие мезенхимальные опухоли с частотой возникновения 2-4 случая на 1 млн человек в год. Они могут возникать как спорадически, так и в ассоциации с семейным аденоматозным полипозом (САП). Природа возникновения спорадических ДФ ранее не была выяснена. Целью исследования было определить возможную значимость герминальных мутаций гена АРС у пациентов со спорадическими ДФ. Экзоны гена АРC амплифицировали и исследовали с помощью конформационно-чувствительного электрофореза в полиакриламидном геле и последующего секвенирования по Сэнгеру. Статистическую обработку результатов проводили с помощью пакета программ «Statistica 10». При исследовании 51 случая спорадических ДФ мутации выявлены у 6 человек (12\%). Пациенты с выявленными мутациями имели характерный фенотип: раннюю манифестацию (в среднем в 5,8 года, в то время как у пациентов без мутаций - в 19 лет ( $p=0,02)$ ); тяжелое течение заболевания; мультифокальный рост ДФ, локализованных на туловище, и неблагоприятный прогноз. Все выявленные мутации были обнаружены в области 3'-конца гена АРС. Для сравнения со спорадическими были исследованы ДФ, связанные с САП (12 человек), мутации выявлены у 6 из них. При мутации в гене АРС у пациентов с САП не было выявлено случаев множественных ДФ, фибромы у пациентов с САП развивались позже (35 лет), чем у пациентов со спорадическими ДФ ( $p=0,004)$ Следовательно, при мутациях в одном и том же гене фенотипы спорадических и ДФ, связанных с САП, различны. Для спорадического ДФ характерно более частое расположение мутаций на З'-конце гена АРС по сравнению с ДФ при САП. Таким образом, впервые среди спорадических ДФ охарактеризован подтип с фенотипическими особенностями, обусловленными герминальными мутациями в гене АРС
\end{abstract}

Ключевые слова: спорадический десмоидный фиброматоз, ген АРС, мультифокальные десмоидные опухоли, семейный аденоматозный полипоз

Информация о вкладе авторов: Т. А. Музаффарова - проведение исследования, работа с литературными данными, оформление рукописи; О. В. Новикова, И. Ю. Сачков - предоставление образцов и клинических данных пациентов; Ф. М. Кипкеева, Е. К. Гинтер - работа с литературными данными, участие в оформлении рукописи; А. В. Карпухин - организация исследования, оформление рукописи.

Соблюдение этических стандартов: исследование одобрено комитетом по этике ФГБНУ «МГНЦ имени Бочкова Н. П.» (протокол № 3 от 09 февраля 2012 г.)

$\bowtie$ Для корреспонденции: Фатима Магомедовна Кипкеева ул. Москворечье, д. 1, г. Москва, 115522; ВRCA1@mail.ru

Статья получена: 25.06.2019 Статья принята к печати: 13.07.2019 Опубликована онлайн: 18.07.2019

DOI: $10.24075 /$ vrgmu.2019.045

Desmoid tumors, also known as desmoid-type fibromatosis (DF), are heterogenous benign neoplasms arising from deep fasciae and aponeuroses. They infiltrate the surrounding soft tissues but do not have the capacity to metastasize. Desmoid tumors are composed of spindle (fibrocyte-like) cells and abundant collagen fibers. A desmoid lacks a capsule and can entrap muscle fibers at the periphery, causing their atrophy. Besides, the tumor can send out long narrow extensions that sometimes reach 20 to $30 \mathrm{~cm}$ in length. 
DF can occur almost anywhere in the body. Based on the lesion site, DF is categorized into extra-abdominal (the abdominal or chest walls, extremities, neck, or pelvis) and intra-abdominal (the mesentery and the retroperitoneum). Technically, desmoid tumors are benign because they do not metastasize. However, they tend to aggressively proliferate and persistently recur after surgical treatment, bearing similarity to cancer [1].

Desmoid tumors can grow enormously large in size and become a life-threatening condition. DF occurs in 2 to 4 per 1 million people a year [2]. Treatment of desmoid tumors is complicated by their propensity for infiltrative growth and locally aggressive behavior. Usually, surgical resection is the preferred option. However, the postoperative recurrence rate remains high, varying from 45 to $90 \%$ [3].

Desmoid tumors either occur sporadically or are associated with familial adenomatous polyposis (FAP), an inherited condition of the colon that eventually transforms into colon cancer. The majority of FAP cases are caused by a mutation in the adenomatous polyposis coli (APC) gene. Ten to fifteen percent of patients with FAP also have DF. The risk of developing DF is 2.56 cases per 1,000 FAP patients a year, which is 852 times higher than in the general population [2]. Unlike sporadic DF, $80 \%$ of FAP-associated desmoid tumors are intra-abdominal. DF predominantly affects women and can manifest itself at any age although the typical age of onset is between 30 and 40 years. Most FAP-associated desmoids develop within 5 years after surgery [4].

The etiology of sporadic DF is uncertain. Some patients with sporadic DF are reported to carry somatic mutations in the APC gene; however, such type of mutations is more commonly found in the CTNNB1 gene that codes for $\beta$-catenin [5-6], a protein involved in the Wht signaling pathway. Mutations in CTNNB1 result in the accumulation of $\beta$-catenin in fibroblast nuclei, which, in turn, disrupts cell differentiation and communication between the cells [7].

Genetic causes of DF and their association with clinical manifestations of the disease remain understudied. Because DF frequently occurs in FAP-stricken patients, it would be natural to hypothesize that predisposition to sporadic DF is determined by mutations in the APC gene. However, the literature on germline mutations in the $A P C$ gene in patients with sporadic DF is scarce [8, 9].

In this work we attempted to estimate the potential significance of germline mutations in the APC gene in a sample of patients with sporadic DF and without a family history of adenomatous polyposis. For the purpose of comparison, we also analyzed molecular characteristics of the APC gene in patients with DF and FAP.

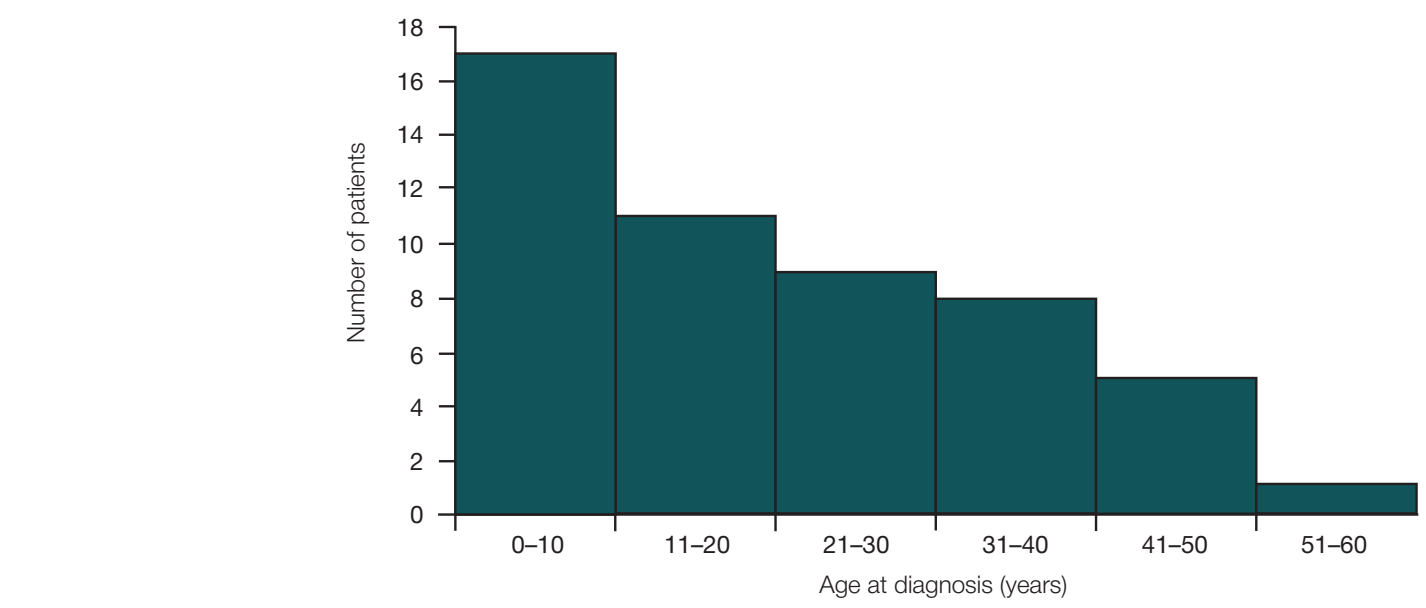

Fig. Age distribution of patients with sporadic DF

\section{METHODS}

The study was conducted at the Laboratory of Molecular Genetics (Bochkov Research Center for Medical Genetics) in 2012-2017. Two patient samples were analyzed. The first sample consisted of 51 patients (21 males and 30 females) with DF. The patients' age ranged from 1 month to 60 years (see Fig.); the median age was 16.8 years. Blood samples were provided by Hertsen Moscow Research Oncology Center where the patients had presented at. The following inclusion criteria were applied: a confirmed diagnosis of DF; no gastrointestinal complaints that could be indicative of diffuse polyposis of the colon; no family history of adenomatous polyposis; no family history of DF. All desmoid tumors in the first patient sample were considered sporadic.

The affected sites included the back, chest and abdominal walls, extremities, and the intra-abdominal region. Multifocal DF was observed in 11 patients (see Results). In some patients the lesions were recurrent.

The second sample comprised 12 individuals $(2$ males and 10 females) shortlisted from a group of 65 patients with FAP who had presented at Ryzhikh State Research Center for Coloproctology; blood samples were provided by the Research Center. The age of onset varied from 24 to 57 years and was 32.5 years on average. The following inclusion criteria were applied: a confirmed diagnosis of colonic polyposis and DF. Eight patients had a family history of adenomatous polyposis. Family histories were not available for 4 patients. In the second patient sample, desmoid tumors appeared after surgery and were localized to the anterior abdominal wall or intra-abdominally. The majority of them were solitary.

DNA was isolated from peripheral blood leukocytes using a standard phenol-chloroform extraction technique [10]. The spectrum of mutations in the $A P C$ gene was analyzed as described in literature [11]. The coding exons of the $A P C$ gene were amplified using exon-specific primers. The PCR products were studied by conformation-sensitive polyacrylamide gel electrophoresis (silver staining). The gene was Sanger-sequenced in order to identify conformational changes to its primary structure. For sequencing, we used a Big DyeTM Terminator v. 3.1 Cycle Sequencing kit and an ABI Prism 3130x1 genetic analyzer (Applied Biosystems; USA). The obtained chromatograms were analyzed in ChromasPro, NCBI BLAST and Ensembl genome browser 91. The NM_000038.6 sequence of the APC gene was used as a reference. Statistical processing was aided by Statistica 10.0 (StatSoft; USA). 


\section{RESULTS}

The APC gene was analyzed in 51 patients with sporadic DF. Six $(12 \%)$ patients were found to carry germline mutations in this gene. Table 1 lists the mutations we detected, the age of the patients at the time of diagnosis, the number of lesions (single or multiple), and their location in the body.

Of 6 detected mutations, 2 were not described previously, including c.4386-4390 delGAGAG (1462delGAGAG) and c.4575ins T (1525insT). Both mutations result in a frame shift and a premature stop codon and are, therefore, deleterious.

The c.4575ins T mutation was found in a female patient (patient 1, see Table 1) with severe DF that manifested at 9 years and was multifocal. The endoscopic examination conducted at the age of 19 years revealed no signs of colonic polyposis.

The mutation c.4386-4390 delGAGAG was observed in patient 2 (Table 1). The onset of the disease occurred at the age of 1 month. Since early childhood, the patient had had multiple growing lesions in the chest wall. By the age of 18 years, the patient had gone through 5 surgical interventions, a few chemotherapy courses, hormone treatment, and radiation therapy, to no avail. This case of DF can be classified as extremely severe and resistant to treatment. The mutation found in patient 2 (c.4386-4390 delGAGAG (1462delGAGAG)) was not previously reported in other populations [12-14]. Also, it was not detected in the blood samples of the patient's parents, so it can be considered a de novo mutation. The sensitivity of the applied method allows detecting 1 to $5 \%$ of mutant alleles, which means that APC mosaicism in the parents is highly unlikely [15].

Three unrelated patients had an identical mutation c.43934394 delAG (1465delAG), whose clinical manifestations were, nevertheless, different. One of its carriers, a 28-yearold woman, had multiple lesions in the chest and abdominal walls and the intra-abdominal region. The age of onset was 17 years. At the time of our study, her colonoscopy was negative for colon polyps. Among the two other patients with the same mutations were a boy with multiple desmoids present at birth (the lesions were localized to the chest and the low back) and a girl with a solitary desmoid tumor on the low back developed at the age of 2 years. Interestingly, the age of onset, the number and location of the tumors were different in those 3 patients. Perhaps, DF sites varied between the patients because 2 of them were quite young. So, we cannot rule out the possibility of multifocal growth later in the children's life. It is also possible that the progression of the disease may be affected by environmental factors and differences in the patients' genotypes.

The c.4348C/T; p.R1450X mutation was detected in 1 patient with multifocal DF. The age at onset was 15 years. The patient had undergone multiple surgeries, a few chemotherapy courses and hormone treatment. By the time of our study, the growth of the tumor had been halted.
All patients with $A P C$ mutations reported an early onset of the disease. Most of them (5 of 6 ) had multiple desmoids resistant to therapy. In spite of the received treatment, the prognosis was still poor for $3(50 \%)$ of patients. DF was severe in 3 of 6 patients with mutant $A P C$, which was more frequent than in the patients who did not carry a germline mutation in this gene (2 of 45$)$. This difference was statistically significant $(p=0.01)$.

The age of onset varied from 1 month to 17 years in the patients with mutant $A P C$ (Table 1), the median age being 5.8 years. In the patients who did not have mutations in the $A P C$ gene, the age of onset varied from 1 month to 60 years (Fig. 1), and the median age was 19 years. The difference in the median values was statistically significant $(p=0.022$; $U$-test).

All APC mutations described above were detected in 6 (23\%) of 26 patients with desmoid tumors on the trunk. Patients with differently localized DF had no mutations in the APC gene (Table 2). Generally, mutations in the APC gene occurred more often in the patients with DF lesions localized to the trunk than in the patients with different lesion sites $(p=0.023)$. This phenomenon is not predicated on the accumulation of multiple desmoid tumors on the trunk (which would indicate random accumulation of the lesions in the carriers of $A P C$ mutations) because the frequency of their occurrence on the trunk was not significantly higher in comparison with other lesion sites (Table 2; $p=0.17)$.

Of 51 patients, 11 had multifocal DF. Five (45\%) of those individuals had germline mutations in the APC gene (Table 1). In the group of patients with solitary DF (40 individuals) only one carried an APC mutation (1/40, or $2.5 \%)$. The difference in the incidence of $A P C$ mutations was statistically significant $(p=0.001)$. The odds ratio value also suggested an association between APC mutations and multifocal DF (OR $=32.5 ; 95 \% \mathrm{Cl}$ : 3.22-326.31). Thus, mutations in the APC gene were mainly seen in the patients with multiple desmoid tumors.

Summing up, the mutations in the APC gene were linked to the tumor location on the trunk and its multifocal growth (Table 2).

Such significant number of mutations (12\%) in the patients with sporadic DF who do not have clinical signs and/or family history of adenomatous polyposis suggest that patients with FAP and patients with sporadic DF can carry different mutations in the APC gene. All mutations detected in the patients with sporadic DF were localized 3' of codon 1444.

Bearing that in mind, we decided to study a sample of patients with FAP and co-occurring DF. Of 65 patients with FAP, 12 had DF. Germline mutations in the APC gene were observed in 6 out of 12 patients with both FAP and DF (Table 3).

Clinical presentations of fibromatosis did not differ between FAP patients regardless of the presence of $A P C$ mutations. The age of DF onset in the FAP carriers of APC mutations varied from 28 to 57 years (Table 3). The median age in this group of patients was 35.5 years; it did not differ significantly

Table 1. Mutations in the APC gene in patients with sporadic desmoid fibromatosis

\begin{tabular}{|c|l|l|l|}
\hline № & \multicolumn{1}{|c|}{ Lesion site } & \multicolumn{1}{|c|}{ Name of APC mutation } & \multicolumn{1}{|c|}{ Age at DF onset } \\
\hline 1 & Multiple lesions; chest and abdominal walls & c.4575insT (1525insT) & 9 years \\
\hline 2 & Multiple lesions; chest and abdominal walls & c.4386-4390 delGAGAG (1462delGAGAG) & 2 months \\
\hline 3 & Multiple lesions; chest wall, lower back & R1450X (c.4348C/T) & 15 years \\
\hline 4 & $\begin{array}{l}\text { Multiple lesions; chest and abdominal walls; intra-abdominal } \\
\text { location }\end{array}$ & c.4393-4394 delAG (1465delAG) & 17 years \\
\hline 5 & Multiple lesions, chest wall, lower back & c.4393-4394 delAG (1465delAG) & 1 month \\
\hline 6 & Back & c.4393-4394 delAG (1465delAG) & 2 years \\
\hline
\end{tabular}


from the median value (29 years; the range of 24-36 years) for the patients who did not have APC mutations.

None of the patients with FAP and co-occurring DF had an APC mutation 3' of codon 1444 (Table 3). In patients with sporadic DF, all detected mutations were located $3^{\prime}$ of codon 1444 (Table 1). The difference in the sites of APC mutations in sporadic and FAP-associated DF was statistically significant $(p=0.0022, \mathrm{OR}=144 ; 95 \% \mathrm{Cl}: 2.43-8517.50)$, i.e. in the patients with sporadic DF, mutations tended to occur at the $3^{\prime}$-region of the gene more often than in the individuals with FAP-associated desmoid tumors.

The patients with sporadic DF and APC mutations tended to develop the condition much earlier in life than carriers of the same mutations with FAP-associated DF (the median age was 5.8 and 35.5 years, respectively; $p=0.004 ; U$-test). No statistically significant differences were observed between the patients who did not have APC mutations but had sporadic or FAP-associated DF in terms of DF onset $(p=0.09)$.

Multifocal DF was more common in the patients with APC mutations and sporadic DF (5/6) than in the individuals with $A P C$ mutations and FAP (0/6): $\mathrm{OR}=60$; 95\% Cl: 1.64-2187.79; $p=0.015$.

\section{DISCUSSION}

In this study, we investigated germline mutations in the APC gene using a sample of 51 patients with sporadic desmoid fibromatosis. All patients had no clinical manifestations or family history of FAP. Six patients (12\%) were found to have pathogenic mutations, two of which had not been reported previously, including 1525insT and 1462delGAGAG. In previous works, APC mutations were studied in patients with sporadic and FAP-associated DF, but detected them only in individuals with FAP but not sporadic DF. This can be explained by specific research objectives or the characteristics of the studied samples. For instance, only 1 case of multifocal DF was included in the sample studied in [16].
It is quite rare that desmoid-type fibromatosis manifests itself in infancy. The available literature presents only several clinical cases of early DF $[17,18]$. In our sample of patients with sporadic DF and APC mutations there were 3 cases of early DF onset: two patients were diagnosed at 1 and 2 months, respectively, and one patient, at the age of 2 years.

In our study, all $A P C$ mutations in the patients with sporadic DF were 3' of codon 1444 and associated with the severe clinical course, multifocal growth and early onset. In this group of patients, the median age at onset was 5.8 years, as compared to 19 years for the patients who did not carry $A P C$ mutations. In the carriers of $A P C$ mutations, all desmoid tumors were localized to the trunk, although such lesion site was not more frequent than other locations (Table 2; $p=0.17)$. This is one of the findings that were unknown previously. There are reports of families with hereditary desmoid tumors. For example, the literature describes a case of a family in which 3 generations have been affected by desmoid-type fibromatosis. Their condition is linked to a frameshift mutation in codon 1924 of the APC gene. In this family, DF were both extra-abdominal and intra-abdominal and the age of onset varies from birth to 10-20 years. Of 9 members of the family, 3 had polyposis or cancer of the colon. Other known cases of inherited DF are also linked to the mutations at the 3'-end of the $A P C$ and characterized by multiple lesions and severe course of the disease $[19,20]$.

It was interesting to compare the features of the detected mutations and DF phenotypes between patients with FAPassociated and those with sporadic desmoid tumors. Research into the association between the patient's genotype and clinical presentations of FAP has yielded controversial results. A study of the association between the site of an APC mutation and the risk of DF in patients with FAP found no such association [21]. Another study of a group of 14 patients with FAP and co-occurring DF revealed that only two patients had the mutation 3' of codon 1444 [22], which might be explained by population characteristics of the sample. In our study, we used

Table 2. Associations between the mutations in the APC gene and different lesion sites/number of desmoid tumors

\begin{tabular}{|l|c|c|c|c|}
\hline \multirow{2}{*}{ Lesion site } & \multicolumn{2}{|c|}{ Patients with desmoid-type fibromatosis } & \multicolumn{2}{c|}{ Patients with multifocal desmoid-type fibromatosis } \\
\cline { 2 - 5 } & Number of patients & Number of patients with mutant $A P C$ & Number of patients & Number of patients with mutant $A P C$ \\
\hline Chest and/or abdominal wall & 26 & 6 & 8 & 5 \\
\hline Intra-abdominal & 3 & - & - & - \\
\hline Extremities & 14 & - & 3 & - \\
\hline Other sites & 8 & - & - & - \\
\hline Total & 51 & & 11 & \\
\hline
\end{tabular}

Table 3. Description of APC mutations and clinical data of patients with FAP and co-occurring DF

\begin{tabular}{|c|c|c|c|}
\hline № & Name of mutations & DF description & Age, years \\
\hline 1 & c.3464-3468 delAAGAA (1155del5) & Postoperative DF of the root of the mesentery & 57 \\
\hline 2 & c.3927-3921delAAAGA (1309del5) & DF of the postoperative scar tissue & 28 \\
\hline 3 & c.3930insA (1310insA) & Postoperative DF of the root of the mesentery & 34 \\
\hline 4 & c.3183-3187 delACAAA (1061del5) & Postoperative DF of the root of the mesentery & 38 \\
\hline 5 & c.2274-2278 delAGCCC p.K758Nfs (758-760 delAGCCC) & Postoperative DF of the abdominal wall & 30 \\
\hline 6 & 3496delT (1166delT) & DF of the abdominal wall & 33 \\
\hline 7 & - & Postoperative DF of the abdominal wall & 33 \\
\hline 8 & - & Postoperative DF of the root of the mesentery & 29 \\
\hline 9 & - & Postoperative DF of the root of the mesentery & 29 \\
\hline 10 & - & Postoperative DF of the abdominal wall & 29 \\
\hline 11 & - & DF of the abdominal wall & 24 \\
\hline 12 & - & Postoperative DF of the abdominal wall & 36 \\
\hline
\end{tabular}


a sample of Russian patients with FAP. Of 65 candidates with FAP, 12 had DF (18\%). This figure is close to that obtained by other researchers: some report a value between 3.5 and $32 \%$ [23], while others, 10-15\% [24]. Half of our patients with FAP and co-occurring DF had mutations in the APC gene. All 6 detected mutations were located at the $5^{\prime}$ of codon 1444. The difference in the incidence of mutations in the region distal to codon 1444 between sporadic and FAP-associated DF was statistically significant $(p=0.002)$. We compared the values obtained for the patients with FAP-associated DF with the occurrence of similarly located mutations in the pooled international sample of FAP patients [25]. The difference was insignificant $(p=0.34)$. At the same time, our values for sporadic DF differed from those for FAP-associated DF reported by other researchers $(p=0.0002)$ [25]. This leads us to conclude that sporadic desmoid tumors occurring in patients with no signs or family history of FAP are more often caused by mutations 3 ' of codon 1444 in comparison with FAP-associated DF.

In our sample, all patients with FAP developed desmoid tumors only after surgery; the tumors occurred either intraperitoneally or in the abdominal wall. Other researchers report the same pattern $[26,27]$.

In our patients with the mutant APC gene, sporadic DF was mainly multifocal and localized to the chest or abdominal walls. Intrabdominal lesions are typical for patients with FAP and less common in sporadic cases of the disease [25]. Most likely, the abdominal location of the tumor in patients with FAP is the result of tissue injury during surgery [28]. No direct association with tissue injury was observed in our study for the patients with sporadic DF and APC mutations.

In our sample, the median age of onset did not differ between the FAP patients with and without mutations, but was significantly lower in the patients with sporadic DF and germline mutations in the $A P C$ gene. For those who did not carry $A P C$ mutations, the age at diagnosis did not differ significantly between the patients with sporadic and FAP-associated DF $(p=0.09)$.

These findings suggest that there is a significant difference in the clinical manifestations of sporadic and FAP-associated desmoid tumors in the carriers of APC mutations; these differences are (at least to some extent) associated with the position of the mutation in the gene.

Summing up, we have studied a sample of individuals with sporadic DF and identified a subgroup of patients with a specific DF phenotype determined by germline mutations in the $A P C$ gene. In such patients, DF is severe, multifocal, manifests itself at early age, resists treatment and has a poor prognosis. The causative mutations are localized to the $3^{\prime}$-end of the APC gene.

Our findings can help the physician in deciding on the suitable treatment strategy and elaborating approaches to polyposis prevention. They can also be useful in studying mechanisms underlying multifocal DF.

\section{CONCLUSIONS}

We have studied a group of patients with DF and no history of FAP and identified a subgroup of individuals with a specific DF phenotype and germline mutations in the APC gene. Unlike patients who do not have APC mutations, carriers of the mutant gene variant develop multifocal DF on the trunk that manifests itself in infancy. In terms of DF phenotype, patients with sporadic DF and APC mutations differ from patients with FAP-associated DF who also have germline mutations in the $A P C$ gene. In patients with sporadic DF, mutations tend to localize to the 3 '-region of the gene. This information should be considered when deciding on the treatment strategy against DF and elaborating approaches to DF and FAP prevention. Our findings provide a basis for the study of molecular mechanisms that trigger primary DF but not FAP.

\section{References}

1. Glebovskaja WV. Thermoradiotherapy of patients with primary and recurrent extraabdominal desmoid [dissertation]. M., 2004

2. Eastley N, McCulloch T, Esler C, Hennig I, Fairbairn J, Gronchi A, et al. Extra-abdominal desmoid fibromatosis: A review of management, current guidance and unanswered questions. Eur J Surg Oncol. 2016; 42 (7): 1071-83. DOI: 10.1016/j. ejso.2016.02.012.

3. Tkashev SI, Aliev MD, Glebovskaja V, et al. The use of thermoradiotherapy in patients with primary and recurrent spasticdominant desmoid tumors. Sarcomas of bones, soft tissues and skin tumors. 2009; (1): 34-7.

4. DE Marchis ML, Tonelli F, Quaresmini D, Lovero D, Della-Morte D, Silvestris $F$, et al. Desmoid Tumors in Familial Adenomatous Polyposis. Anticancer Res. 2017 Jul; 37 (7): 3357-66.

5. Mullen JT, DeLaney TF, Rosenberg AE, Le L, lafrate AJ, Kobayashi W, et al. $\beta$-Catenin mutation status and outcomes in sporadic desmoid tumors. Oncologist. 2013; 18 (9): 1043-9. DOI: 10.1634/ theoncologist.2012-0449.

6. Alman BA, Li C, Pajerski ME, Diaz-Cano S, Wolfe HJ. Increased beta-catenin protein and somatic APC mutations in sporadic aggressive fibromatoses (desmoid tumors). Am J Pathol. 1997; 151 (2): 329-34. PubMed PMID: 9250146; PubMed Central PMCID: PMC1857985.

7. Nikulin MP, Petrosyan AP, Tsymzhitova NTs, Gubina GI. Retroperitoneal desmoids: analytical review and case report. Clin Experiment Surg. 2015; (4): 103-12.

8. Koskenvuo L, Peltomäki P, Renkonen-Sinisalo L, Gylling A,

Nieminen $\Pi$, Ristimäki $A$, et al. Desmoid tumor patients carry an elevated risk of familial adenomatous polyposis. J Surg Oncol. 2016; 113 (2): 209-12. DOI: 10.1002/jso.24117.

9. Brueckl WM, Ballhausen WG, Förtsch T, Günther K, Fiedler W, Gentner B, et al. Genetic testing for germline mutations of the APC gene in patients with apparently sporadic desmoid tumors but a family history of colorectal carcinoma. Dis Colon Rectum. 2005; 48 (6): 1275-81. DOI: 10.1007/s10350-004-0949-5.

10. Sambrook J, Fritsch EF, Maniatis T. Molecular cloning: a laboratory manual, N.Y.: Cold Spring Harbor Laboratory, Cold Spring Harbor, 1989; $1546 \mathrm{p}$.

11. Muzaffarova TA, Mansorunov DJ, Sachkov IY, Kuzevanova AY, Karpukhin AV, Alimov AA. Molecular genetic aspects of the risk for family adenomatous polyposis. Molecular medicine. 2018; 16 (6): 60-64.

12. The Human Gene Mutation Database (HGMD ${ }^{\circledR}$. Available from: http://www.hgmd.cf.ac.uk/ac/index.php.

13. Ensembl Genome Browser 96. Available from: http://www. ensembl.org/index.html.

14. LOVD database. Available from: https://www.lovd.nl/.

15. Hes FJ, Nielsen M, Bik EC, Konvalinka D, Wijnen JT, Bakker E, et al. Somatic APC mosaicism: an underestimated cause of polyposis coli. Gut. 2008; 57 (1): 71-6. DOI: 10.1136/gut.2006.117796.

16. Kattentidt Mouravieva AA, Geurts-Giele IR, de Krijger RR, van Noesel MM, van de Ven CP, van den Ouweland, et al. Identification of Familial Adenomatous Polyposis carriers among children with desmoid tumours. Eur J Cancer. 2012 Aug; 48 (12): 1867-74. 


\section{DOI: 10.1016/j.ejca.2012.01.004}

17. Dalit A, Karen M, Alexander M. Congenital desmoid tumor of the cheek: a clinicopathological case report. Eplasty. 2009 Nov 10; (9): e52. PubMed PMID: 20011031; PubMed Central PMCID: PMC2779781.

18. Roggli VL, Kim HS, Hawkins E. Congenital generalized fibromatosis with visceral involvement. A case report. Cancer. 1980; (45): 954-60.

19. Halling KC, Lazzaro CR, Honchel R, Bufill JA, Powell SM, Arndt CAS, et al. Hereditary Desmoid Disease in a Family with a Germline Alu IRepeat Mutation of the APC Gene. Hum Hered. 1999; (49): 97-102.DOI: 10.1159/000022852.

20. Eccles DM, van der Luijt R, Breukel C, Bullman $H$, Bunyan $D$, Fisher A, et al. Hereditary desmoid disease due to a frameshift mutation at codon 1924 of the APC gene. Am J Hum Genet. 1996; 59 (6): 1193-201. PMCID: PMC1914868; PMID: 8940264.

21. Nieuwenhuis $\mathrm{MH}$, De Vos Tot Nederveen Cappel W, Botma A, Nagengast FM, Kleibeuker JH, Mathus-Vliegen EM, et al. Desmoid tumors in a dutch cohort of patients with familial adenomatous polyposis. Clin Gastroenterol Hepatol. 2008; 6 (2): 215-9. DOI: 10.1016/i.cgh.2007.11.011

22. Torrezan GT, da Silva FC, Santos EM, Krepischi AC, Achatz MI, Aguiar S Jr, et al. Mutational spectrum of the APC and MUTYH genes and genotype-phenotype correlations in Brazilian FAP, AFAP, and MAP patients. Orphanet J Rare Dis. 2013; (8): 54. DOI: 10.1186/1750-1172-8-54

\section{Литература}

1. Глебовская В. В. Терморадиотерапия больных с первичным и рецидивным экстраабдоминальным десмоидом [диссертация]. M., 2004.

2. Eastley N, McCulloch T, Esler C, Hennig I, Fairbairn J, Gronchi A, et al. Extra-abdominal desmoid fibromatosis: A review of management, current guidance and unanswered questions. Eur J Surg Oncol. 2016; 42 (7): 1071-83. DOI: 10.1016/j. ejso.2016.02.012.

3. Ткачев С. И., Алиев М. Д., Глебовская В. В. и др. Применение терморадиотерапии у больных первичными и рецидивными зкстраабдоминальными десмоидными опухолями. Саркомы костей, мягких тканей и опухоли кожи. 2009; (1): 34-7.

4. DE Marchis ML, Tonelli F, Quaresmini D, Lovero D, Della-Morte D, Silvestris $\mathrm{F}$, et al. Desmoid Tumors in Familial Adenomatous Polyposis. Anticancer Res. 2017 Jul; 37 (7): 3357-66.

5. Mullen JT, DeLaney TF, Rosenberg AE, Le L, lafrate AJ, Kobayashi W, et al. $\beta$-Catenin mutation status and outcomes in sporadic desmoid tumors. Oncologist. 2013; 18 (9): 1043-9. DOI: 10.1634/ theoncologist. 2012-0449.

6. Alman BA, Li C, Pajerski ME, Diaz-Cano S, Wolfe HJ. Increased beta-catenin protein and somatic APC mutations in sporadic aggressive fibromatoses (desmoid tumors). Am J Pathol. 1997; 151 (2): 329-34. PubMed PMID: 9250146; PubMed Central PMCID: PMC1857985.

7. Никулин М. П., Петросян А. П., Цымжитова Н. Ц., Губина Г. И. Забрюшинные десмоиды: аналитический обзор и случай из практики. Клиническая и экспериментальная хирургия. 2015; (4): 103-12.

8. Koskenvuo L, Peltomäki P, Renkonen-Sinisalo L, Gylling A, Nieminen TT, Ristimäki A, et al. Desmoid tumor patients carry an elevated risk of familial adenomatous polyposis. J Surg Oncol. 2016; 113 (2): 209-12. DOI: 10.1002/jso.24117.

9. Brueckl WM, Ballhausen WG, Förtsch T, Günther K, Fiedler W, Gentner B, et al. Genetic testing for germline mutations of the APC gene in patients with apparently sporadic desmoid tumors but a family history of colorectal carcinoma. Dis Colon Rectum. 2005; 48 (6): 1275-81. DOI: 10.1007/s10350-004-0949-5.

10. Sambrook J, Fritsch EF, Maniatis T. Molecular cloning: a laboratory manual, N.Y.: Cold Spring Harbor Laboratory, Cold Spring Harbor, 1989; $1546 \mathrm{p}$.

11. Музаффарова Т. А., Мансорунов Д. Ж., Сачков И. Ю., Кузеванова А. Ю., Карпухин А. В., Алимов А. А. Молекулярногенетические аспекты риска семейного аденоматозного
23. Fallen T, Wilson M, Morlan B, Lindor NM. Desmoid tumors - a characterization of patients seen at Mayo Clinic 1976-1999. Fam Cancer. 2006; 5 (2): 191-4. DOI: 10.1007/s10689-005-5959-5.

24. Lips DJ, Barker N, Clevers H, Hennipman A. The role of APC and beta-catenin in the aetiology of aggressive fibromatosis (desmoid tumors). Eur J Surg Oncol. 2009 Jan; 35 (1): 3-10. DOI: 10.1016/j.ejso.2008.07.003.

25. Nieuwenhuis $M H$, Lefevre $J H$, Bülow $S$, Järvinen $H$, Bertario $L$, Kernéis $\mathrm{S}$, et al. Family history, surgery, and APC mutation are risk factors for desmoid tumors in familial adenomatous polyposis: an international cohort study. Dis Colon Rectum. 2011; 54 (10): 1229-34.DOI: 10.1097/DCR.0b013e318227e4e8.

26. Nieuwenhuis $M H$, Lefevre $J H$, Bülow $S$, Järvinen $H$, Bertario $L$, Kernéis $\mathrm{S}$, et al. A nation-wide study comparing sporadic and familial adenomatous polyposis-related desmoid-type fibromatoses. Dis Colon Rectum. 2011 Oct; 54 (10): 1229-34. DOI: 10.1002/ijc.25664.

27. Koskenvuo L, Ristimäki A, Lepistö A. Comparison of sporadic and FAP-associated desmoid-type fibromatoses. J Surg Oncol. 2017 Nov; 116 (6): 716-21. DOI: 10.1002/jso.24699.

28. Nieuwenhuis MH, De Vos Tot Nederveen Cappel W, Botma A, Nagengast FM, Kleibeuker JH, Mathus-Vliegen EM, et al. Desmoid tumors in a dutch cohort of patients with familial adenomatous polyposis. Clin Gastroenterol Hepatol. 2008 Feb; 6 (2): 215-9. DOI: 10.1016/j.cgh.2007.11.011.

полипоза. Молекулярная медицина. 2018; 16 (6): 60-4. DOI: https://doi.org/10.29296/24999490-2018-06-11.

12. The Human Gene Mutation Database $\left(\mathrm{HGMD}^{\circledR}\right)$. Available from: http://www.hgmd.cf.ac.uk/ac/index.php.

13. Ensembl Genome Browser 96. Available from: http://www. ensembl.org/index.html.

14. LOVD database. Available from: https://www.lovd.nl/.

15. Hes FJ, Nielsen M, Bik EC, Konvalinka D, Wijnen JT, Bakker E, et al. Somatic APC mosaicism: an underestimated cause of polyposis coli. Gut. 2008; 57 (1): 71-6. DOI: 10.1136/gut.2006.117796.

16. Kattentidt Mouravieva AA, Geurts-Giele IR, de Krijger RR, van Noesel MM, van de Ven CP, van den Ouweland, et al. Identification of Familial Adenomatous Polyposis carriers among children with desmoid tumours. Eur J Cancer. 2012 Aug; 48 (12): 1867-74. DOI: 10.1016/j.ejca.2012.01.004

17. Dalit A, Karen M, Alexander M. Congenital desmoid tumor of the cheek: a clinicopathological case report. Eplasty. 2009 Nov 10; (9): e52. PubMed PMID: 20011031; PubMed Central PMCID: PMC2779781.

18. Roggli VL, Kim HS, Hawkins E. Congenital generalized fibromatosis with visceral involvement. A case report. Cancer. 1980; (45): 954-60.

19. Halling KC, Lazzaro CR, Honchel R, Bufill JA, Powell SM, Arndt CAS, et al. Hereditary Desmoid Disease in a Family with a Germline Alu IRepeat Mutation of the APC Gene. Hum Hered. 1999; (49): 97-102.DOI: 10.1159/000022852.

20. Eccles DM, van der Luijt R, Breukel C, Bullman H, Bunyan D, Fisher A, et al. Hereditary desmoid disease due to a frameshift mutation at codon 1924 of the APC gene. Am J Hum Genet. 1996; 59 (6): 1193-201. PMCID: PMC1914868; PMID: 8940264.

21. Nieuwenhuis MH, De Vos Tot Nederveen Cappel W, Botma A, Nagengast FM, Kleibeuker JH, Mathus-Vliegen EM, et al. Desmoid tumors in a dutch cohort of patients with familial adenomatous polyposis. Clin Gastroenterol Hepatol. 2008; 6 (2): 215-9. DOI: 10.1016/j.cgh.2007.11.011.

22. Torrezan GT, da Silva FC, Santos EM, Krepischi AC, Achatz MI, Aguiar S Jr, et al. Mutational spectrum of the APC and MUTYH genes and genotype-phenotype correlations in Brazilian FAP, AFAP, and MAP patients. Orphanet J Rare Dis. 2013; (8): 54. DOI: 10.1186/1750-1172-8-54

23. Fallen $\mathrm{T}$, Wilson M, Morlan B, Lindor NM. Desmoid tumors - a characterization of patients seen at Mayo Clinic 1976-1999. Fam Cancer. 2006; 5 (2): 191-4. DOI: 10.1007/s10689-005-5959-5. 
24. Lips DJ, Barker N, Clevers H, Hennipman A. The role of APC and beta-catenin in the aetiology of aggressive fibromatosis (desmoid tumors). Eur J Surg Oncol. 2009 Jan; 35 (1): 3-10. DOI: 10.1016/j.ejso.2008.07.003.

25. Nieuwenhuis $M H$, Lefevre JH, Bülow S, Järvinen $H$, Bertario L, Kernéis S, et al. Family history, surgery, and APC mutation are risk factors for desmoid tumors in familial adenomatous polyposis: an international cohort study. Dis Colon Rectum. 2011; 54 (10): 1229-34.DOI: 10.1097/DCR.0b013e318227e4e8.

26. Nieuwenhuis $M H$, Lefevre $J H$, Bülow $S$, Järvinen $H$, Bertario L, Kernéis $S$, et al. A nation-wide study comparing sporadic and familial adenomatous polyposis-related desmoid-type fibromatoses. Dis Colon Rectum. 2011 Oct; 54 (10): 1229-34. DOI: 10.1002/ijc.25664.

27. Koskenvuo L, Ristimäki A, Lepistö A. Comparison of sporadic and FAP-associated desmoid-type fibromatoses. J Surg Oncol. 2017 Nov; 116 (6): 716-21. DOI: 10.1002/jso.24699.

28. Nieuwenhuis MH, De Vos Tot Nederveen Cappel W, Botma A, Nagengast FM, Kleibeuker JH, Mathus-Vliegen EM, et al. Desmoid tumors in a dutch cohort of patients with familial adenomatous polyposis. Clin Gastroenterol Hepatol. 2008 Feb; 6 (2): 215-9. DOI: 10.1016/j.cgh.2007.11.011. 